\title{
Cultural citizenship without state: historical roots of the modern Polish citizenship model
}

\section{Tomasz Zarycki $^{1}$ D $\cdot$ Rafał Smoczyński $^{2}$ (D) $\cdot$ Tomasz Warczok $^{1} \mathbb{D}$}

Accepted: 2 October 2021 / Published online: 30 October 2021

(c) The Author(s) 2021

\begin{abstract}
Citizenship is usually seen as a product of modern nation-states, or of other political entities which possess institutional infrastructures and political systems capable of producing a coherent framework that defines the relationship between that system and its members. In this paper, we show that an early system of modern citizenship was created in the absence of a formal state, notably by the cultural elite of a stateless nation. The Polish case illustrates that an elite may become a dominant class in the given society only later, and institutionalize that early citizenship system within the framework of a newly founded state. As a result of the legacy of the emergence of citizenship predating the restoration of statehood, the contemporary Polish citizenship model is influenced by a strong and largely overlooked cultural component that emerged at the turn of the 19th century. This model uses the figure of the intelligentsia member as its ideal citizen. Despite the dramatic political and economic changes in the decades which have passed since its emergence, this cultural frame, which was institutionalized during the interwar period, still defines the key features of the Polish citizenship model. Consequently, we argue that the culturalization of citizenship is hardly a new phenomenon. It can be seen as a primary mechanism in the formation of civic polities within the imperial context. Moreover, it shows that such processes can have many ambiguous aspects as far as their Orientalizing forces of exclusion are concerned.
\end{abstract}

Keywords Citizenship · Cultural citizenship · Poland · Central-Europe · Intelligentsia $\cdot$ Cultural capital

Tomasz Zarycki

t.zarycki@uw.edu.pl

1 University of Warsaw, Warsaw, Poland

2 Institute of Philosophy and Sociology of the Polish Academy of Sciences, Warsaw, Poland 


\section{The intelligentsia as the naturalized frame for the Polish citizenship model}

The notion of citizenship in the classical literature on the subject is usually related to the multidimensional, but the predominantly political, concept of belonging to a well-defined political entity. The relationship between citizenship and a clearly defined political community, initially a city, then a state, seems fundamental in most of its definitions (e.g. Heater, 2004, Turner, 1997). It also has a definite direction; it is the political organism today, primarily the nation-state, that creates and defines the framework of its citizenship. In our text, we would like to demonstrate that this classical dynamic does not represent the only possible path for the formation of a citizenship system. In the case of Poland, we can point to an under-examined process of the emergence of a political community that gradually produced its definition of citizenship in the absence of a state structure. The case of Poland demonstrates that a political community founded by the elite of a stateless nation divided between three imperial administrations was not only able to reconstruct its modern mythology and national identity at the turn of the 20th century but also was able to agree on an autonomous framework of civic belonging, which was parallel to the still existent formal citizenship in the old imperial states of Austria, Prussia, and Russia. This framework has proven to be largely determined by cultural criteria and remains so to this day, as we will argue in this paper. Importantly, this framework is not restricted to traditional criteria such as ethnic, religious, or linguistic identities. It also has a much deeper, naturalized, and normative frame which largely defines social hierarchies in Poland up to the present day. The legacy of the Polish model, rooted in a culturally deterministic model of citizenship, is an argument for the fact that this phenomenon (a nonpolitically constructed citizenship) already has a long history. This is because it challenges the assumption of much of the current work on the given phenomenon, which usually implies that it should be regarded as a relatively recent trend in the evolution of the Western citizenship model. In other words, it is presented as a new layer of citizenship, defined either through the visible, the political, or economic, or through other invisible metrics. Culturalization, as will be demonstrated below, may be understood as the rise of the role of cultural rather than purely political or economic criteria for full membership in a civic community. It is also important that cultural criteria in such a context do not necessarily imply purely national or ethnic cultural competencies or identities. They may refer to much more nuanced cultural registers used as tools of exclusion. Thus, our broader argument here is that a clear differentiation between ethnic or national cultural criteria of the definition of citizenship, on the one hand, and cultural criteria naturalized through the figure of the ideal citizen, on the other, may be very helpful in studying the historical roots of the modes of exclusion that contemporary citizenship models use. The interpretation we offer in this paper is, first of all, an alternative reading of the history of the Polish model of citizenship, which is usually studied from the point of view of its mechanisms and functions of ethnic exclusion and inclusion. Moreover, we present the notion that the 
Poles experienced a revolution-like moment in 1918 that has been understated and poorly understood so far. Besides challenging the dominant reading of the Polish case, our theorization may also improve the understanding of general cultural citizenship processes. It may inspire studies of citizenship models in nations that gained their formal statehood later than most Western nations states or even those that remain stateless until this day. At the same time, it may also inspire the deconstruction of the historical turning points in dominant narratives of national histories, which emphasize elements of continuity overshadowing revolutionary changes.

As our case suggests, this can happen because the rising factions of elites may claim the legitimization of the new order using the narrative frame of "revival" and attempt to take over the identities of the old elite. By offering this comparative study of the case in Poland, which has had a fractured history of statehood in the last century, we show that the development of the modern notion of citizenship is not necessarily directly linked to well-defined statehood. Let us also remember that after being restored in 1918, the Polish state was again non-existent from 1939 to 1945. The interwar (1918-1939) Polish state was rather weak and torn apart by political animosities and clashes of the state with its diverse ethnic groups. Thus, our perspective may also help study the emergence of the independent civic sphere and the rise of other aspects of national autonomy in an imperial or colonial context. In this way, this paper may be seen as a contribution to the field of global sociology of empires, one which emphasizes studying the historical roots of national citizenship models of states that were only established in the 20th century (Go, 2009; Steinmetz, 2014).

We argue in particular that the Polish citizenship model is informed by a substantial and largely overlooked cultural component that emerged at the turn of the 20th century and has been based ever since on the figure of the intelligentsia member as its ideal citizen. The notion of the intelligentsia is of crucial importance in this context. There is a wide array of approaches to, and definitions of, the intelligentsia (Gella, 1976; Kennedy, 1992; Sdvižkov, 2006; Walicki, 2005). We use a rather technical definition following the model proposed by Eyal et al. (1998) in which the intelligentsia may be defined as an elite of cultural capital; in this way, they are contrasted to the bourgeoisie or the elite of economic capital and the elite of political capital. The latter typically included the so-called Soviet nomenklatura. From the perspective of world-system theory, the intelligentsia may also be seen as a substitute for a weak or non-existent bourgeoisie in the European semi-periphery (Wallerstein, 1974-1989). Economic dependence of the semi-periphery makes the long-term accumulation of economic capital difficult or impossible. As a result, most roles that the bourgeoisie play in the societies of the Western core are taken over by elites of the cultural capital, which appears more stable in economically and politically volatile contexts.

In such an approach, the intelligentsia is seen as a social group having aspects of both strata and class; given the social system in Central and Eastern European countries, this can be framed as a dual stratification order (Zarycki, 2015). The Polish intelligentsia is usually understood as a product of the transformation of petty nobility into an educated elite of what had initially been a stateless society. In the 
case of the Russian intelligentsia, the sons and daughters of orthodox priests had also been considered, at the turn of the 19th and 20th centuries, to be an important source of the first generation of the intelligentsia. In Poland, the Catholic Church, in turn, played the role of a crucial ally of the intelligentsia elite and, for a large part of the Polish intelligentsia, loyalty to the Catholic religion was and remains to this day, a component of Polishness. In both countries, however, Christians were not the only groups making up the intelligentsia elite. Of particular importance were Jews, who usually entered and developed more secular and often left-oriented factions of the intelligentsia. The intelligentsia also assimilated, although usually not in high numbers, people of other ethnic, religious ${ }^{1}$ and social origins, including educated peasant sons and daughters, impoverished aristocrats, or industrialists.

We contend that, despite this considerable diversity of the intelligentsia as a social elite in both countries, in the case of Poland, there has existed a pretty well defined, even if an informal, clear set of values and criteria which has framed the ideal intelligentsia member. These values become particularly apparent during conflicts between the intelligentsia's elite factions, both historically and today. Through discursive fights, factions try to devalue their opponent's status in the intelligentsia elitist hierarchy or even exclude them entirely. However, these acts of attempted exclusion render the common values and identities of the intelligentsia, such as disinterested service to national and social causes as well as a commitment to excel in general education, apparent. We share the view that such a type of social elite is unique and can be mostly found in Poland, Russia, and some other Central and Eastern European societies, such as Hungarian or Ukrainian societies. As Alexander Gella (1976) or Garry Saul Morson (1993) point out, the intelligentsia should not be confused with intellectuals, given that the latter assume only a certain specific social role, while the intelligentsia is deeply embedded in the social structure. The intelligentsia is a social group that locates families or even clans of several generations at the core of its identity. A family origin, by the way, appears to be a much stronger social asset defining someone's intelligentsia status than one's education or intellectual involvement. Members of the intelligentsia elite do not necessarily have to be formally educated. Of much higher value for their groups is familial socialization, a general erudition or fluency in foreign languages.

Despite dramatic political and economic changes in the decades which have passed since the emergence of this cultural frame, which had been institutionalized during the interwar period (1918-1939), it still defines the key features of the Polish citizenship model. We will present a detailed discussion of the process of development of this specific model. However, our main aim is to show in the Polish context, that what is commonly called the culturalization of citizenship, does not necessarily constitute a new phenomenon as has been argued by Evelien Tonkens and Jan Willem Duyvendak or Jan Pakulski (1997). Pakulski, for example, wrote about cultural citizenship as a relatively recent aspect of the development of modern civil societies in which cultural rights have become both an extension of civic rights and

\footnotetext{
${ }^{1}$ For example, several families of Tatar origin are known to be members of the network of the so-called old intelligentsia, some of whom are today, members of Poland's Muslim community.
} 
a new dimension of inequality. In turn, Tonkens and Duyvendak argued that only until relatively recently citizenship was first and foremost tied to possessing nationality (Tonkens \& Duyvendak, 2016: 3) and only globalization and mass migration have prompted the problematization of the relationships between the state, culture, and citizenship (Tonkens \& Duyvendak, 2016: 6). As we argue, the process of the crystallization of modern Polish nationhood implied the emergence of an informal citizenship model, which, due to the absence of the Polish state in the 19th and early 20th centuries, was defined primarily in cultural terms. In other words, culturalization could be understood as preceding the institutionalization of citizenship. This process should be, of course, related to the historical circumstances of the emergence of the modern Polish nation, which were determined by control over Polish territory from 1795 until 1914 by three empires: Austrian-Hungary, Prussia, and Russia, with the Romanovs' empire dominating over the largest part of the territory and population of what would become independent Poland in November of 1918. To be exact, it must be noted that Germany controlled most of this realm between 1915 and 1918, which was a brief but formative period for the nation-states of Central and Eastern Europe; states that mostly emerged at the former imperial borderland from entities created by the German occupational administration. Our analysis allows us to relate the Polish case of discussion on "imperial citizenship regimes" and their bifurcation to contemporary national citizenships systems (Harrington, 2015: 55). Moreover, it also links the debate on orientalist, colonialist, and imperial prefiguration of citizenship (Isin, 2015: 4) to our analysis on the redefinition of the relations between state and citizenship. The latter has been, for example, noted by Aoileann Ní Mhurchú, who remarked that contemporary experiences of political belonging and identity may often no longer fit with the regularity of existing state sovereign politics (Ní Mhurchú, 2014:125). However, in this paper, looking, in particular, at the turn of the 20th century in Central and Eastern Europe, we argue that such a dissociation of political identity and formal citizenship was also common in the period of the demise of European empires. Following this line of inquiry, we intend to, first of all, enrich the emerging debates on the colonial and orientalist roots of many of the contemporary citizenship regimes pointing to a possible interpretation of the cases from Central and Eastern Europe falling within the same paradigm. These cases will undoubtedly widen the spectrum of the new paradigm. On the other hand, the application of the given perspective to countries like Poland may allow us to add a new dimension to debates on their citizenship models, which remain rather narrowly centered on national perspectives. Attempts at inscribing the cases of the Polish and other Central European national cultures into the post-colonial and orientalist perspective have been made earlier (e.g., Buchowski, 2006, Bakić-Hayden, 1995, Cobel-Tokarska, 2020 or Melegh, 2006). Disputes over the ambiguous places that given nations and cultures occupy in chains of a post or neo-colonial domination or dependence seem quite inspiring and far from over. Nevertheless, none of these works deal directly with questions of citizenship, while it seems that Orientalizing aspects of citizenship in several of the states of the region cannot be understood without referring to the frame of post-colonial theory.

The emergence of the Polish statehood and the Polish citizenship model in 1918 is usually related to attempts to build national identities based on opposition to 
other national cultures or ethnicities. Historically, such a clearly defined program of nation-building has been promoted by the rising national movement, best represented by the National Democracy (Endecja) party from the late 19th century onwards. It was opposed by the left-oriented parties, which advocated for a more inclusive vision of Polishness. Both movements strengthened following the 1905 revolution and gradually dominated the Polish political scene.

The left, led by the Polish Socialist Party and one of its leaders - Józef Piłsudski, and the National Democrats, under the leadership of Roman Dmowski, were gaining the upper hand, while the conservatives and liberals loyal to the imperial administrations were gradually losing influence due to the increasing political mobilization of the masses. The conflict between Piłsudski and Dmowski dominated the interwar period. They represent, respectively, two paradigmatic definitions of the Polish nation and two models of citizenship. On the one hand, Piłsudski's federalist project assumed a union or confederation of countries of Central Europe located between Germany and Russia, with Poland as their leader. This vision involved a non-ethnic-based political definition of the nation. Dmowski, on the other hand, advocated a Polish nation-state with a clear emphasis on the ethnic definition of citizenship. However, following the French model, he also supported cultural citizenship and unified polity, which would be helpful to impose Polish culture on minorities. He was, nonetheless, aware of the weakness of Polish administrative resources, which were not sufficiently efficient to homogenize the entire population of a multi-ethnic country in the foreseeable future. Therefore, Dmowski proposed the Catholic Church to be the crucial ally of the state in its nation-building mission (Porter, 2011). He also spoke against extending Poland's Eastern border too far, as he feared that the resulting growth of the population of ethnic minorities would become uncontrollable. Piłsudski, in contrast, was a proponent of the broader eastwards extension of Polish borders. The interesting paradox is that Piłsudski's multiculturalism was often criticized as a form of Polish imperialism and was rejected by most neighboring nations, or at least by the majority of their elites, and, in several instances, even backfired causing severe tensions which have lasted until the present day-as, for example, the conflict between Poland and Lithuania (Böhler, 2018). The paradox, here, refers to the perception of Piłsudski's role in contemporary Poland. While Dmowski, with his ideas of cultural homogenization and Catholitization of Poland, is widely perceived, especially on the liberal and even more on the left side of the Polish political spectrum, as a negative point of reference - with an incarnation of a model of Polish nationalism and even anti-Semitism, Piłsudski's role usually has been seen as, at least neutral or even cast in a very positive light. His federalist ideas and criticism of Dmowski's nationalism are identified as forms of Polish multiculturalism, an inclusive variant of Polishness. The Piłsudski-Dmowski ideological binary, although very visible, did not exhaust the multi-dimensional process of the emergence of Polish citizenship. Both were intelligentsia-centered models of citizenship with the naturalized symbolic status of the intelligentsia as an ideal citizen at their core.

Thus, our argument relies on the assumption that two dimensions of citizenship should be carefully distinguished. The first concerns overt exclusionary and inclusionary modes of all categories of significant others, that is, non-citizens. These 
modes are crucial for all modern Central and Eastern Europe nation-states and often have ethnic or/and religious components. The second concerns implicit hierarchies of the civic sphere, which allow for the categorization of citizens and the consequent implicit depreciation of certain would-be citizens. The latter, which we will call cultural, may not necessarily be based on ethnic criteria but rather on other less apparent distinctions defined primarily through employing distance strategies from the normative figure of the ideal citizen.

We rely here on TH Marshall's well-known discussion of the model citizen figure for modern societies (Marshall, 1964). Marshall described the British model in which the ideal citizen is personified by a gentleman and opposed to the American one, which has an entrepreneur as its prototypical type. In this paper, we argue that the Polish equivalent of such a figure, at least since 1918, has been an intelligentsia member, who has acted as an ideal type of Polish citizen. Since the first formal dimension of citizenship in Poland and its overt rules of exclusion and inclusion are relatively well described in the academic literature (e.g. Górny et al., 2005, Górny \& Pudzianowska, 2009), this paper will be primarily focused on the historical roots of the second dimension of the Polish citizenship model, although the first will be also briefly discussed. To be sure, both dimensions are related in many ways. What seems to be most important from our point of view is that the second dimension, which will be discussed at length in this paper, is often used to conceal acts of exclusion which may be defined primarily along the first dimension, that is by ethnicity, religion or previous/second citizenship status. This is because the second dimension based on the hegemonic status of the intelligentsia ideals is better naturalized. Its high degree of legitimization, which, as we will argue, is shared across all the main political forces in Poland, allows a much more effective way of excluding unwanted fellow citizens or potential citizens. It was thus used at many occasions to exclude from full citizenship rights representatives of Jews, Belarussians, Ukrainians, and above all representatives of the lower classes, but in ways which did not name their identities overtly as reasons of exclusion, pointing instead to deficits of civic values defined by the intelligentsia's ideals perspective.

\section{Early development of the Polish citizenship model}

Let us start with Jeffrey Alexander's (2006) model of the civic sphere, the so-called community of formally equal citizens of any modern country. As Alexander noted, this sphere is always, in fact, a strongly hierarchical social space. Its hierarchies are based mostly on naturalized cultural norms and the implicit values of any society. This is possible because citizens are always expected to fulfill several expectations or even internalize them (e.g., moral virtues, which are exemplified by figures of model citizens, who can be considered as secular saints). These virtues are defined somewhat vaguely, but in most cases, competent citizens follow the rules unconsciously and generate normative frames of behavior. What is at stake in any critical analysis is not the factual correctness of references to historical narratives, but the ability to use a given frame to categorize actors within the civic sphere at a given moment. 
Of particular importance are the religious roots of the modern idea of civil society, which can be seen as a secular faith based on a set of binary codes: pure and impure symbols placed in opposition to each other. According to Alexander, any community is built on a specific moral discourse that involves ideas of solidarity and binary opposition between the moral and immoral. At the same time, he understands the civic sphere as the third dimension of solidarity besides economics and politics, a space whose contours have to be sustained by the state. There are three dimensions in which binary opposition within the civic sphere is defined as particularly important. These are, as Alexander calls them, "motives", "relations", and "institutions"; in all of them the distinction between rational vs. irrational is arguably decisive. This distinction can be linked to Foucault's vision of modern societies as ruled by the symbolic mechanism of discipline based on the division of the social world into acceptable and unacceptable ideas of behavior. The latter are coded as irrational and perverted, which engenders both reliance on self-control as the fundamental mechanism of social regulation and the implicit rather than the explicit rule of exclusion and hierarchization, all of which are critical aspects of governmentality (Foucault, 1980).

Social order organized according to this logic is possible because the binary codes of the civic sphere have been naturalized and they form both an uncontested axis of the organization of community and a key point of reference for social communication. What remains negotiable are the mechanisms of their use and the interpretation of political and social conflicts. Alexander admits that the development of modern civic societies contains an essential dimension of inclusion or cooptation of new cultural identities into the broadly defined repertoire of civic identities or what Jan Pakulski (1997) calls cultural citizenship. Thus, any modern society is defined by prior acts of formal inclusion into the civic community (e.g., an extension of civil rights to women or ethnic minorities). The order in which groups were endowed with formal civic rights largely reflects their place in the informal hierarchy of social prestige. Those co-opted later usually enjoy lower status as the latecomers' identities might be considered as fully compatible with the citizenship ideals only after some time. However, even then they may still be seen as less prestigious than the group identities of founding elites of a given polity. Alexander challenges, for instance, American and French myths of universal civic incorporation while discussing the hidden American history of marginalization of Germans, exclusion of Jews, Catholics, and several other minorities, which have been gradually co-opted to the American symbolic universe, but the status of their identities is sometimes still considered as not fully equal to WASP cultural identity status.

We posit that the way Alexander reconstructs mechanisms of the exclusion and marginalization of the American civic sphere, which in turn produces informal cultural and social hierarchies of contemporary American society, can be used as a tool for the analysis of historically produced implicit hierarchies of citizenship in other countries such as Poland. We will, therefore, attempt to reconstruct the process of gradual cooptation of new social groups, which have been moving upward in the hierarchy of civic identities. These groups may be defined in ethnic, racial, cultural, religious, or gender categories, however, during the upward mobility process, the social hierarchy remains stable. Even if particular ethnicities, races, or genders 
are formally or informally included in the privileged sector of the civic sphere and endowed with political and economic rights, the general informal, cultural hierarchy persists concerning the first members of a given polity. The latter remains as the dominant actors perceived as perfect incarnations of the original ideal citizens. Alexander assumes that assimilation requires the abandonment of "impure old parts" of co-opted groups' identities, which usually occurs by moving them into the private sphere.

The purification of the public sphere is accompanied by another parallel process, namely that of acquiring civic competencies. It is one of the critical mechanisms of homogenization and imposition of dominant codes (i.e., values, identities, and lifestyles). This is because socio-political claims, to be recognized as valid, have to be articulated as core identities of a given civic sphere. This is one of the critical reasons why old hierarchies persist in the social space of most Western societies. In effect, in e.g. American society, as Alexander claims, the Protestant identity still has higher standing than a Catholic one, even if it may be seen as a post-religious, cultural identity. English culture and language are implicitly valued higher than Mexican culture and Spanish language just as the cultural status of North-Western European identities is more appreciated than those of Eastern Europe.

Jeffrey Alexander (2006) also argued that the classic model of modern citizenship in most Western societies evolved from a feudal society, which was politically led by an aristocracy based principally on the knights' ethos and evolving into capitalism informed by the Protestant ethic. Such ambiguity of transition between aristocratic privilege and citizen's status has also been noted by other Western scholars. Philip Dawson saw the citizen as defined in opposition to a privileged aristocrat (Dawson, 1993: XIV). Joseph Carens, on the other hand, argued that "citizenship in Western liberal democracies is the modern equivalent of feudal privilege" (Carens, 1987: 252) implying, as André Liebich noted, that feudal privilege may be the medieval equivalent of citizenship (Liebich, 2009: 25). As we argue below, a parallel process could be identified in Poland, namely, a movement from the common European aristocratic knight's ethos to the intelligentsia republican ethos. Its side-effect is that descendants of the high nobility still enjoy a special status in Poland even if they should be seen as a rather marginal faction of the upper class (Jakubowska, 2012). The peripheral location of Poland on the map of Europe caused both the Reformation and the development of modern capitalism to be relatively restricted. In particular, the bourgeoisie did not emerge in Poland as a dominant social class. Instead, it had mainly been replaced by what is called the intelligentsia, or the cultural bourgeoisie, which in turn had imposed its values and identities as dominant (Jedlicki, 1999). However, before that happened, and the ideal intelligentsia member had become a model Polish citizen in the early 20th century, an interesting confrontation within the Polish elite took place.

During the 19th century, we have witnessed the development of several competing Polish citizenship models. On the one hand, traditional noble and aristocratic citizenship ideals were still in place. On the other hand, the new landowner's citizenship model was emerging as a result of economic transformation, in particular, due to the emergence of a group of wealthy individuals acquiring large estates who did not necessarily have the noble pedigree. The old noble citizenship was based on 
the old feudal census and had the figure of an aristocrat as its ideal citizen. In other words, it was noble social-capital-based citizenship. The emerging landowner's citizenship was based on the land ownership census and used a landowner (ziemianin) as its ideal citizen, thus it was informed by an economic capital census. A crucial moment in the confrontation between these two models and respective factions of the Polish elite took place in the late 18th century, before the so-called partition of the First Republic of Poland. The conflict materialized in the clash over the Polish constitution of May 3rd, 1791, which is known until today as the first constitution to be adopted in Europe, and the second in the world after the American one. This constitution, which had no lasting effects on the polity, as it was terminated along with the Polish state in 1795 , nevertheless had a crucial symbolic meaning, and the day of its adoption has been celebrated as a state holiday until today. What is often less remembered is that the 1791 constitution deprived impoverished nobles, who did not possess landed property, of their fundamental civil rights, in particular, the voting right at the assemblies of nobility (Sejm). This could be understood as the introduction of an economic census, and the marginalization of the nobility by an emerging landed gentry. Until that moment, Poland was known as the noble democracy inspired by the ideal of Greek and Roman republics, with a strong emphasis on the equality of its citizens irrespective of economic or aristocratic titles. Aristocratic titles had been abolished in Poland during the Middle Ages, and only reintroduced because of the union with Lithuania established in 1569; solely Lithuanian princely titles had been legally recognized in the Commonwealth. However, even then, all members of the nobility were considered equal citizens with voting rights at the assembly that elected the king. Polish historians have boasted until today about the supposedly largest enfranchised share of inhabitants in any European country in Early Modern Europe. As Janusz Tazbir argues, at the end of the 18th century some 8 to $10 \%$ of the Christian (this calculation excludes all Jews enjoying self-governing rights) population had been ennobled and thus could be seen as having full civil rights (Tazbir, 2013: 54).

In contrast, the bourgeoisie was devoid of most of these privileges until the adoption of the 3rd of May Constitution of 1791. Nobility membership was also made more accessible for burghers to acquire. With half a million burghers in the Commonwealth who, since the implementation of the constitution, had been substantially enfranchised, landed citizenship took precedence over noble citizenship during the 19th century. Aspects of this process included the impoverishment of the petty nobility, which either had dissolved into the peasantry or had migrated to urban areas and transformed into the intelligentsia - a new stratum that will be discussed below (Gella, 1976). The imperial administrations of the Austrian, Prussian, and, in particular, Russian Empires undertook systematic efforts at stripping a significant fraction of the Polish petty nobility of their titles. This was made through the forced re-registration of noble privileges based on verification of the noble status in the documented record, which a significant part of the Polish petty nobility lacked. This was also because no institutionalized heraldic office had ever existed in Poland. Importantly, estates of the impoverished noble families were bought by enriched non-nobles. In the second part of the 19th century, the richest of the representatives of the bourgeoisie started 
to intermarry with the old aristocracy, thereby acquiring noble titles. This was also done through an ennoblement process carried out by Austrian or Russian monarchies, often as a result of purchasing noble titles. Becoming landed citizens, the new landowners and bourgeoisie were also adopting a specific lifestyle and, in this way, had become an equivalent of the English gentry (which acquired full civic rights in Britain in 1852). In other words, a new hybrid class emerged, partly recruited from the old aristocracy, partly from the new bourgeoisie, and partially also of Jewish origin. The old citizenship model had been marginalized and replaced with the new hybrid "landed citizenship" model. The notion of "landed citizen ("obywatel ziemski") gained currency in the second part of the 19th century (Jakubowska, 2012). Quite often as its synonym, simply the word "obywatel" (citizen) was used, which testifies to its dominant status. Its ideal figure was a wealthy landowner with a noble title, but one not necessarily acquired by birth. On the opposite end of the hierarchy of social prestige, we find the figure of a landless peasant as an incarnation of the non-citizen.

Since the second half of the 19th century, a new axis of the confrontation assumed a central position. Namely, the clash between the rising intelligentsia, or the cultural-capital-based elite, and the elite of the gentry allied with the bourgeoisie had increased. The latter alliance could be seen as a united block of the old and new economic capital elite. In effect, the model of the landed citizen was challenged by the concept of intelligentsia citizenship, which referred to the ideal of universal citizenship with no economic or feudal census. The intelligentsia citizenship model has never been uniform; it has always contained several variants (e.g., socialist, nationalist, etc.), as we will discuss below. However, it has been informed by consistent common democratic assumptions, which have contradicted the landowner citizenship model. It has been a relatively inclusive model, oriented towards the masses and related to the nation-state building project. Most importantly, it has been hypothesized as a class-less model society that was based on the ideal of the creation of a "modern Pole," a counterpart of a modern German, Italian, or Frenchman. The ideal citizen was a typical intelligentsia member, that is to say, a well-educated, cultured individual with a strong ethos of service for the country (the latter, depending on political orientation, could be defined as either an ethnic nation or a civic community). An ideal intelligentsia member could have had but did not necessarily require, noble family roots or even aristocratic relatives. But, he or she, first of all, should have declared a readiness to sacrifice one's interests for the nation's sake; in the leftist faction of the elite, this would be construed as a sacrifice for the disadvantaged classes of the nation. Such an ideal citizen has historically served in an insurgency, in political underground activism, and/or gotten involved in formal or informal military combat to fight directly or indirectly for the national cause. Thus participation in anti-Russian uprisings or anti-communist resistance/opposition was established as a strong point of reference for a new emerging generation of the intelligentsia. Through critically interrogating the model of supposedly universal citizenship, which has been advocated by the intelligentsia since the 19th century onwards, we can see its implicit hierarchies built through the ideal citizen as an intelligentsia member. 


\section{Historical roots of the intelligentsia citizenship model}

Looking at the emerging Polish political scene at the turn of the 20th century we can identify its four basic camps: conservatives, liberals, socialists, and nationalists; in addition, peasant political parties also existed. Conservatives and liberals were mostly members of elite movements representing the interests of landowners, bourgeoisie, and part of the urban intelligentsia, in particular, the faction of the intelligentsia oriented towards careers in political and economic systems of the Austrian and Russian empires. These groups could be related to what Jack Harrington calls 'actors trying to redefine imperial citizenship' in late colonial periods. From the point of view of their radical opponents, they could be understood as colonial subjects who enacted the empire through, for example, volunteering in World War I or standing for elected office in the metropole (Harrington, 2015: 56). In general, the Polish national movement, just as most of its counterparts that were relevant to anti-colonial and nationalist discourse formations had its origins in claims for political, cultural, and social rights within the imperial polity (Harrington, 2015: 63). However, only the conservatives and liberals clearly inscribed themselves in the renegotiation of rights within the platform of imperial polity and often collaborated with all-imperial liberal and conservative parties, such as the Constitutional Democrats (Kateds) in Russia. They also served in imperial governments, such as Polish conservatives who achieved the highest posts possible in the Austrian administration.

There were intelligentsia-led movements that aspired to mobilize the masses against the establishment of empires. The beginning of mass politics in Poland is usually identified with the revolution of 1905 in the Russian Empire when mass political parties (e.g. the Polish Socialist Party and the National Democrats) achieved considerable success in the mobilization of the masses against the imperial administration (Marzec, 2020). Peasants were the subject of competition between the various factions of the intelligentsia and the Empires. However, the entire 19th century could be analyzed as a period of confrontation between landowners and the emerging intelligentsia. Major Polish uprisings, specifically those of 1830 and 1863, and less directly the uprisings of 1905 (actually, the development of the 1905 Russian revolution started in Polish provinces) and 1944 (the Warsaw uprising), can be seen as transformative for the emerging Polish field of power in their achieving hegemony through intelligentsia narratives. These uprisings had been supported by most of the intelligentsia members (or their petty and impoverished nobility predecessors) and opposed or treated with suspicion by the economic capital elites. The latter (the majority of landowners and significant parts of the emerging bourgeoisie) in most cases were dependent on the political and economic systems of the empires controlling Polish lands. The primary outcome of uprisings which ended up in disastrous defeats, as far as their military dimension is concerned, was the gradual marginalization of the economic elites and the rise of the intelligentsia. The failed uprising also provided a useful narrative for the rising intelligentsia, as they were and still are presented as acts of self-sacrifice carried out by the intelligentsia for the nation. Interestingly, 
their heroes are not portrayed solely as citizen-soldiers but also as intelligentsia members sacrificing their lives for the national cause. A good example of this is the figure of the young poet Krzysztof Kamil Baczyński (1921-1944), who died in the Warsaw Uprising. He stands in the center of the narrative that the intelligentsia gave their "best sons" to the fatherland. The intelligentsia's ideology was based on calls for national liberation and resistance against occupants and "traitors" who cooperated with the imperial regimes. Also, those doing business with economic actors representing foreign (primarily imperial) companies were considered as 'comprador' or immoral, which also reveals an important aspect of the intelligentsia's anti-bourgeois identity. The core intelligentsia ideology comprised a critique of pre-modern feudal elites, principally under slogans of social emancipation, equality, modernization, and democratization; landowners were increasingly portrayed as a backward, pre-modern and oppressive class.

In addition to the intelligentsia's growing ideological pressure, the economic elite of Poland in the second part of the 19th century had also suffered material losses. While the bourgeoisie had been developing steadily, the landowners experienced a major blow - declining profitability of their estates (Mich, 2000). The critical turning point for both groups' plight was the Russian Bolshevik (October) Revolution 1917, which resulted in the loss of a significant part of the land and financial assets of the Polish economic elite. Later, the peace treaty of Riga signed in 1921 between the newly re-established Polish state and the Soviet Union, or more precisely the Russian and Ukrainian Socialist Republics sealed the fate of the once hegemonic elite of the Polish bourgeoisie and landowners. It resulted in the confiscation of their properties in territories that became part of communist Russia. What was at stake at that time was not only a huge material loss for these elites but also the specific perception of these assets. The landowners and bourgeoisie attempted to present their losses as crucial blows to "national wealth" (Grocholski, 1929). Conversely, the victorious intelligentsia elite presented the very same assets as the private property of a selfish upper class detached from Polish society. Władysław Grabski, the chief Polish negotiator of the Riga Treaty, argued that "Poland cannot be identified with the ownership rights of this narrow group" (Grabski, 2016: 84). Grabski, who later become the prime minister of Poland, criticized what he called the idea of a 'landowners Poland' as a delegitimized entity from the perspective of peasants. The support of the peasantry was crucial in this period, because of the ideological confrontation with the Bolsheviks who tried to attract Polish lower classes to their cause. One can interpret this position as a denial of the defense of economic interests of the old landowning elite by the intelligentsia, presented as a necessary price of political inclusion of the peasantry in the newly institutionalized Polish intelligentsia-centered civic community.

The wealthy nobility was not able to universalize its traumatic experience of the horrors related to the Bolshevik Revolution, the Great War occurrences, and the establishment of communist rule, which included brutal dispossessions, murders, rapes, and exile, among other atrocities. Several books published in the interwar period were authored by representatives of the landowner elite who had been exiled from lands that eventually became a part of the Soviet Union [e.g. „Conflagration” (Kossak, 1923) or „Storm from the east” (Dunin-Kozicka, 1925)], These books, 
however, did not become part of the national narrative dominated by the intelligentsia's suffering under Russian, German or Austrian rule. This failure of the universalization of the group's traumatic experience was an essential dimension of the political and economic marginalization of the old economic elite. This seems to confirm Jeffrey Alexander's view of trauma as a social construction (Alexander, 2012).

\section{The invisible Polish revolution}

Kathryn Wegner argues that analysis of political revolutions in the modern world should be central to the historiography of global citizenship, since it is, in revolution, that assertions of individual desire for liberty redefine the relationship between people and their ruler(s) and forge new citizenships. (Wegner, 2014: 141). Thus, we propose to interpret the developments in Poland of 1918 as an invisible or unnamed Polish Revolution parallel to the Russian (October) Revolution. Interestingly, as Aidan Beatty noted, the notion of revolution may be ambiguous in peripheral countries. For example, in Ireland (Beatty, 2016) the Irish Revolution (1912-1923) had most clearly manifested aspects of national liberation, and, to a limited extent, socioeconomic aspects as well, as a significant fraction of large estates in Ireland were returned to their original owners. Beatty also notes a similar case in the Egyptian Revolution of 1919, which contained weak economic and social aspects and a dominant national liberation component. However, the case of the Polish 1918 transformation, which was never proclaimed to be a revolution, stands in opposition to the Irish and Egyptian ones where transformations, which had been confined to aspects of national sovereignty were proclaimed as revolutionary. In Poland, the 1918 transition could be seen as a radical break with previous social hierarchies, not just a moment for regaining national sovereignty. It was undoubtedly the founding moment of the modern Polish state as well as its citizenship model from then onwards. To a large extent, it can be compared to the French Revolution as a universalized myth of the French nation, even though it is lesser appreciated than the mainstream historical narratives of the May 3rd, 1791 constitution and the national uprisings of 1830, 1863, and 1944. The relative invisibility of the Polish revolution of 1918 may have paradoxically reinforced its crucial universalized role. One of its central myths implied that the new Polish state is the direct successor of the First Republic or Rzeczpospolita, that is to say, the Polish-Lithuanian Commonwealth. The First Republic has been commonly idealized as one of the most advanced democracies of its period, while the Second Rzeczpospolita or inter-war Poland (1918-1939) remained, in a way, a follow up of a noble republic since it extended, at least formally, civic rights to all of its inhabitants; symbolically, it ennobled the entire population. This act of unconditional universalization of noble citizenship carried out by the intelligentsia might be viewed as the core of a social revolution and has had visible effects to this day, as in the linguist convention of addressing any citizen as "sir" (pan). Obviously, until 1918, neither workers nor peasants were addressed in this way. Importantly, this linguistic convention is related to a key symbolic binary of the Polish civic sphere. Namely, it refers to a "lord" and "boor" opposition ("pan" and "cham"), which was also universalized and assumed a doxic character after 
1918. Boor (cham), originally meaning a peasant, also denoted all those who did not enjoy civic rights and did not deserve social respect. When citizenship rights became universalized, the category of "boor" started to denote all those not fulfilling the expectations of respected citizens. The lord-boor opposition has become increasingly relative and contextual. Anyone may be called a "boor" who is located lower in the social hierarchy.

One should note that, in Poland, the first government of the Second Republic established in 1918 was a social-democratic coalition, and it introduced several crucial political and social reforms, including the abolishment of feudal titles (more precisely, the Polish state ceased to recognize them as legally binding), full gender equality and universal voting rights, and land reform, which limited the size of estates to 180 hectares (400 hectares in Eastern Borderlands - areas exceeding this limit were to be parceled out to peasants for compensation). Until the declaration of sovereignty (formally published on November 7th, 1918), central Poland, which remained under German control during the First World War (from 1915 until November 1918), had a semi-autonomous administration headed by the Regency Council of the Kingdom of Poland, which was supposed to become an independent monarchy in the German sphere of influence after the war. German general Hans Hartwig von Besseler headed the Council and included some Polish aristocrats and wealthy landowners in it. It was mostly a representation of the conservative elites actively cooperating with the Russian Empire until 1915 and then, after that, the German state. In other words, many of them switched allegiance from Imperial Russia to Germany, but, on November 14th, 1918, the Council passed all its authority to Józef Piłsudski, who assumed the title of the Supreme Leader of the State (Kauffman, 2015).

Beginning with the first parliamentary elections to Sejm in 1919, the representations of bourgeoisie and landowners were weak. Most of their representatives joined the Popular National Union (Zwiazek Ludowo-Narodowy), which in 1928 morphed into the National Party (Stronnictwo Narodowe). In that political force, they were marginalized by the intelligentsia members (Nałęcz, 1994). The same could be said about landowners and bourgeoisie representation in the National Democracy (Endecja), which implied political marginalization. The once prominent Polish liberal circles related to progressive factions of the bourgeoisie, which had considerable representation in the Russian Duma (e.g., among Kadets) after 1918, gradually waned, eventually disappearing almost without a trace. For this reason, Andrzej Jaszczuk entitled a book about this group, "The Liberal Atlantis" (Jaszczuk, 1999).

At the same time, Piłsudski, the leader of the independence movement and military commander of the Polish troops, has since been considered as an incarnation of an ideal intelligentsia figure. Born into a petty nobility family, he was active in the socialist movement in the Russian Empire and acted as a member of the Polish Socialist Party. The newly born Polish Republic, under his leadership, granted its citizenship to all residents of the Republic irrespective of their ethnicity, class, or religion. However, even the criterion of permanent place of residence was not easy to interpret during the foundational period as the borders of the country were unstable and only defined around 1921 while the first citizenship law was adopted in January 1920 (Weredyńska-Szpakowska, 2016). Besides the criterion of residency, the 
other option for citizenship acquisition included the possibility of choosing Polish citizenship by former citizens of the three empires and, analogically, choosing citizenship of another country by Polish residents who did not identify with the Polish state (Pokoj, 2014). One can note, in this context, that external pressure was also a factor shaping the legislation of the Second Republic. It was stipulated in the Treaty of Versailles (1919) that ethnic minorities in the territory of newly formed Poland should be provided with citizenship and equal rights (Fink, 2006; Sharp, 1991) ${ }^{2}$.

\section{Communist Poland}

Thus, the emergent Polish model of citizenship was driven by cultural capital as the central asset of the national intelligentsia-led Republic, while the Soviet model was primarily based on political capital as the main asset of the new communist elite. Interwar Poland, although a relatively weak state, nonetheless provided generous funding for its elite public university and high school system, as well as for the state-run institutions of culture and science. This resulted in a considerable rise in the number of university graduates in the first years after the restitution of independence (Popiński, 2018). Some 40 thousand students studied in the 1920s, while in the 1930s, these numbers reached about 50 thousand. A similarly steep rise in the number of university students occurred after the Second World War. During the first post-war academic year of 1945-1946, some 56 thousand students were enrolled. By 1950, that number more than doubled, reaching 125 thousand. This growth then slowed, with 165 thousand enrolled in 1960.

Communist Poland, where a communist party nomenklatura acted as a national elite, represents the most radical example of a strong state project implemented under Soviet control (1944-1989). However, the nomenklatura or the purely political capital-based elite, project failed without challenging the hegemony of the intelligentsia in the long run (Eyal \& Townsley, 1995) ${ }^{3}$.

In Poland, during the Stalinist period of 1948-1953, a genuine politically centralized authoritarian system was installed. Side effects of that period were, in fact, beneficial to the intelligentsia, as they resulted in dispossessions of the main former competitors of the intelligentsia, namely the landowners and remnants of the bourgeoisie. The elite of the former has assumed the position of an intelligentsia

\footnotetext{
2 The current question of minorities rights in Poland has been discussed in detail by Peter Vermeersch (2009).

3 The relationship between the nomenklatura and the intelligentsia is complicated and depends on the historical context. While in their paradigmatic forms, they may be considered as opposing types of elites (of political capital and cultural capital respectively), many of the nomenklatura members had an intelligentsia family origin or belonged to the elite intelligentsia circles. The nomenklatura can also be seen as one of the projects of the intelligentsia (or, in particular, of one of the intelligentsia factions, principally in the Soviet Union). On the other hand, regarding Poland, one can argue that the nomenklatura project was never able to challenge the intelligentsia hegemony. One example is a study by Agata Zysiak (2016) that analyzed the establishment of Łódź University in 1945 as a new model school for elites of the communist country. As Zysiak convincingly demonstrates, it became another typical Polish university that quickly began educating the new generation in the cult of classic intelligentsia figures.
} 
sub-group, while the latter ceased to exist as a coherent social group (Smoczyński \& Zarycki, 2021). In a similar period in Soviet Russia a significant part of these classes, including most of the old intelligentsia, were annihilated (Tchouikina, 2006). The ideal Soviet citizen was a working-class origin official, worker or possibly a soldier, but always a communist party member loyal to the state and ready to sacrifice for the ideals of socialism.

The intelligentsia citizenship model in Poland was only partly redefined during the communist period. In official communist discourses, the notion of the "working intelligentsia", as a supposedly socialist and progressive incarnation of the old intelligentsia ideal, was promoted between 1945 and 1989. However, the communist government could not challenge the above-mentioned linguistic convention of addressing strangers as "sir" (pan), which assumed the universalization of civic rights through inclusion in the symbolic universe of nobility. To be sure, communists made some efforts to eradicate this convention in the Stalinist period, when they promoted addressing fellow citizens as "citizen" (obywatel) or "comrade" (towarzysz). However, these attempts failed miserably. During the same period, reliance on leftist rather than conservative values of the intelligentsia was encouraged, but this did not challenge the overall intelligentsia-dominated model. With the weakening of communist rule, these biases have slowly waned.

\section{The ideal Polish citizen}

Since 1918 landowners and aristocracy have been marginalized and their heritage, including lifestyle and distinction, partly taken over and redefined by intelligentsia elites. Since that time, the intelligentsia has acted as a dominant actor in the Polish field of power, and its citizenship model has remained unchallenged. What was crucial, however, for the post-1918 redefinition of social hierarchies was that the aristocratic, or more generally noble distinction, had been taken over by the victorious intelligentsia elite from the nobility. This seems to be a process very similar to the adoption of the aristocratic distinction by the French upper bourgeoisie (Bourdieu, 1984). Besides Bourdieu's "Distinction", this process was described more systemically by a Polish sociologist, Maria Ossowska in her "Bourgeois morality" (Ossowska [1956] Ossowska, 1986). As she argued, after its victory, the triumphant class (in the French case - the bourgeoisie) abandoned is traditional patterns in order to adopt patterns of the class which had previously been the privileged one (Ossowska, 1986: 314). Ossowska called this phenomenon ,interference of the bourgeoise and noble patterns in the 19th century". One could note that similar observations, in particular regarding the timorousness of Germany's bourgeoisie and their deference to aristocracy were made by Eckart Kehr (1965) and Max Weber (1968). Importantly, Ossowska discussed three essential threads of criticism of the bourgeoisie. The first thread is leftist criticism of political oppression and exploitation of the working class, egoism, and arrogance. The second thread is criticism of interestedness, narrow-mindedness and dual morality articulated by those identified with nobility. The third thread is the bohemian criticism of bourgeois morality as hypocritical and lacking of fantasy. One could note that all these lines of criticism 
had been widely waged by the intelligentsia in Poland during the period of its confrontation with the landowners and bourgeoisie elites at the turn of the 20th century (Mich, 2000).

To conclude, our analysis of the transformation of the Polish citizenship model begun with its shift from the nobility-based system into two competing models in the second part of the 19th century. The first one emerged already in the late 18th century, in the short-lived May 3rd constitution of 1791, and included the gradual introduction of economic census. In the second part of the 19th century, an alternative redefinition of noble citizenship developed, one which was underpinned by a cultural capital census in its elite aspects. It had been usually associated with the intelligentsia, which can be theorized as a cultural bourgeoisie (Eyal et al., 1998). At the turn of the 20th century, the two models had been competing on equal footing along with their elites. The landowners' model declined while the intelligentsia model of citizenship emerged as victorious. Since 1918, that intelligentsia model has been perceived as formally inclusive and universal, but has also included an implicit normative frame built into it which could be theorized in terms of culturalization, that is to say, an informal census of cultural capital. The intelligentsia model defined the ideal citizen as a cultured, well-educated intelligentsia member with a strong ethos of responsibility for social and national well-being. The model also implicitly assumed that the ideal citizen may have a noble origin and, although critically oriented towards landowners and the bourgeoisie, he or she may be an heir of a redefined knight's ethos featuring e.g. courage and honor. The significant other of the intelligentsia ideal citizen was a "boor," that is a landless peasant lacking the qualities mentioned above. Thus a boor was a functional non-citizen, or dysfunctional citizen, while the ideal citizen, as a symbolic "lord," was defined as a member of the new functional aristocracy of the republic. Although the new implicit aristocracy was perceived not in terms of the old feudal census, but in line with intelligentsia ideals, the old aristocracy, or the descendants of the elite of the Polish nobility and landowners, remained as an important symbolic point of reference for the new elite. The representatives of the old aristocratic families (which became a sub-field of the intelligentsia) represent a living proof of the continuity of the Polish state and its elite from the early middle ages onwards and remain both a pattern of elegance and a pattern of the national moral leadership (Jakubowska, 2012). Hence, in the informal hierarchy of the modern Polish civic sphere, the elite of the intelligentsia, in particular, old intelligentsia families (as well as the elites of the former aristocratic and landowning families) occupy the highest position. They are represented by the intelligentsia clans widely known by their members active over several generations as public intellectuals, scholars, civil servants, or political leaders. Their family names appear in history textbooks and contemporary mass media. ${ }^{4}$ Lower

\footnotetext{
${ }^{4}$ One good example of publications documenting and promoting prominent clans of the intelligentsia is a collection of their histories published by Magdalena Bajer under the auspices of the Foundation for Polish Science (FNP) (Bajer, 2013, 2019). Among historic families with living members in the Polish academic and, at times, political elite presented by Bajer, such names as Achmatowicz, DuninWąsowicz, Grabski, Romer, Mycielski, Sobański, Staniszkis, Strzembosz, Woźniakowski, Tarnowski, Toeplitz, Ziółkowski, or Zoll could be mentioned.
} 
in the hierarchy are groups that have been co-opted into the civic sphere with some delay. This effected the process that Jeffrey Alexander (2006) identified in the American context. Groups included later were not fully recognized as fulfilling the ideals of the intelligentsia citizenship. In the Polish context, peasants, workers, and ethnic minorities appeared lower in the informal civic hierarchy, even if this fact was never admitted publicly by anyone representing state institutions and the social or political elites.

That being said, the strength of this informal hierarchy is apparent, and its persistence is clear in the results of both quantitative and qualitative studies. For instance, long term analysis of education and occupational status hierarchies points to a superior status of intelligentsia-related social roles and jobs and the lower standing of not only farmers and manual workers but also better-paid cadres and directors of private firms, which are not associated with ethos or social mission (Domański et al., 2018). During communism, as well as in contemporary capitalism, a university professor has enjoyed the highest position in the social prestige hierarchy in Poland. Discourse analysis points to the persistently high status of the old intelligentsia elites, even if their members often reject such direct identifications (Kulas, 2017). Moreover, systematic studies of the contemporary intelligentsia elite clearly show that the narrow group of descendants of the former landowners and aristocratic families enjoys constant and considerable informal prestige (Smoczyński \& Zarycki, 2021).

The revolutionary moment of 1918 also marked the co-optation of women, who gain their full suffrage. The Second Republic unequivocally granted them passive and active electoral rights. For the first time, they could exercise these rights in the parliamentary elections of 1919, in which eight women representing various political orientations took parliamentary seats. Such a diversity of women's representation in the parliament shows fairly widespread support for their inclusion in the civic sphere, although, before 1918, it was slightly higher on the side of the socialists than the nationalists, whose leaders kept their distance from the demands of political equality (Gawin, 2015). However, there are two perspectives on this inclusion of women. The more critical one emphasizes that 1918 was only the first step in the full inclusion of women in Polish public life. Their representation in parliament remained minimal for a very long time. Moreover, they did not usually occupy major public functions. Inequalities in this regard persist to this day, and they can be explained precisely by the fact that the formal moment of granting citizenship rights occurred only in 1918. Additionally, the right to vote should not be equated with actual equality and the significant participation of women in parliamentary politics - in independent Poland, there was de facto gender inequality. The March Constitution of 1921 acknowledged the legal and political equality of citizens in its preamble. However, systemic gender inequality existed in civil law, culture, political activity, and access to certain professions. After the adoption of the constitution, the 19th-century rules in the former Russian part of the country, under which a wife owed obedience to her husband, could not dispose of her property and income from work, or sue in court without her husband's consent, were changed. It is difficult, however, to assess how quickly the customs associated with the abolished law changed. Importantly, under the Civil Service Act of 1922, married women could enter the public service only with their husband's consent. Women were not appointed to judicial positions 
until 1929, and from 1928, they could not serve as jurors. Women, however, won the opportunity to practice as advocates - by the outbreak of World War II, about 200 women had become advocates in Poland (Kysko, 2015). On the other hand, we have a narrative that points to aspects in which the position of women in Poland has not been worse than in many European countries, e.g., the gender gap in earnings between men and women has long been lower in Poland than the European average (Boll et al., 2017). Additionally, although general access to higher education in prewar Poland was very difficult, in the 1930s, women accounted for 27 percent of the total number of students (Popiński, 2019) - similar to France and Great Britain, but more than in Austria, Italy, Germany, Spain, the Netherlands, and Sweden (Ringer, 2004: 248). There are narratives explaining the relative advantages of Poland in the process of women's emancipation and indicating that their place in the intelligentsia model of citizenship was already relatively high in the late 19th century. Moreover, for a large part of the intelligentsia, the struggle for women's emancipation became part of the struggle for national independence. This may be related to the images of women active in uprisings (one of the earliest and best-known examples of them is the figure of Emilia Platter, a female commander in the October Uprising of 1831) and the "patriotic" aspects of activities of women's organizations appearing at the turn of the 19th and 20th centuries. The chance for the realization of their postulates was often seen in the success of the struggle for independence, which had the synergistic effect of valorizing the position of women in the intelligentsia model of citizenship defined in opposition to the partitioning powers.

What seems ambivalent in this context is the legacy of women's activism in landed gentry circles, which can be read as an ideological framework for women's place in the landed gentry model of citizenship. Its main institutional framework was the "United Landowners Women Circle" (Zjednoczone Koło Ziemianek) (Maj, 2017). On the one hand, it clearly distanced itself from feminism and avoided any direct political demands. However, it worked for the equality of women, using as a point of reference the relatively prominent role played by Polish landowners' wives in the management of the estates. Even if this idealized image retained basic class differences between women, it implied that the landed gentry model of citizenship was progressive in this area. This contributed to the fact that the 1918 "intelligentsia revolution" did not meet with much resistance from the old landowners elite as far as the extension of political rights to women was concerned.

Given the nature of the hierarchy built around the figure of the ideal intelligentsia member, it is possible to discuss the question of the location of specific individuals on the scale extending between good exemplary citizens and those failing to meet the criteria of "good citizenship", informally called "boors". This could also be seen as an early form of what authors such as Evelien Tonkens and Jan Willem Duyvendak describe as the culturalization of citizenship in the Netherlands, where culturalization implies that citizens are expected to embrace liberal democracy, secularism, and progressive values regarding gender and sexuality. (Tonkens \& Duyvendak, 2016: 9). In the Polish case, good citizens were and are supposed to embrace values of Polish high culture, social progress, modern patriotism, and social responsibility. Again, this becomes visible in the analysis of public discourse (Bilewicz, 2015; Radiukiewicz, 2021). This informal expectation also includes the discourses of 
the émigré intellectuals, which, during the entire post-war era, retained patterns of exclusion of the non-intelligentsia figures from the idealized circle of good citizens of the community of exiled Poles. Systematic studies of discourse on "Kultura", published monthly in Paris between 1947 and 2000 and enjoying substantial prestige in Poland, have been performed by Anna Horolets and Joanna Bielecka-Prus (Horolets \& Bielecka-Prus, 2016, 2017). They point to the systematic depreciation or even mocking of exiled Poles of working-class and peasant origin, those involved in "trade", and women. Contemporary studies of the Polish migrants in Western Europe also point to the vitality of symbolic hierarchies of built-in intelligentsia values among the Polish diaspora (Smoczynski et al., 2017). In the Dutch narrative, as presented by Tonkens and Duyvendak, secularism, sexual liberties, and liberal democracy merge with Orientalist discourses of the "Muslim" and a "backward" other who is deemed sexually repressed and incapable of respecting the social and political equality of women and sexual minorities. In this way, progressive "Dutchness" separates natives from immigrants, with sexuality being one of the important lines of demarcation (Tonkens \& Duyvendak, 2016: 10). In the Polish case, the intelligentsia-dominated model of citizenship may also be used to separate native Poles from immigrants or new citizens. This particularly concerns all those arriving in Poland from the countries of the former Soviet Union, such as Ukraine. They are sometimes depreciated in the public sphere, and although there are few direct racist attacks, there may also be veiled acts of stigmatization as lower-class co-citizens or "boors".

Josip Kešić and Jan Willem Duyvendak argue that the broader relevance of studies of the Dutch case lies in the fact that it shows how national essentialism and chauvinism can occur even in attempts to denounce nationalism's essentialism, and can manifest in more subtle, complex and unexpected ways (Kešić \& Duyvendak, 2016). This is, in fact, quite clear in the Polish case, at least from the early $20^{\text {th }}$ century until today, where most progressive and leftist discourses systematically use orientalist narratives of exclusion to frame all those who are un-civic as Eastern and boorish (Zarycki, 2014). The Polish citizenship model, in contrast to what is often publicly declared (for example, by emphasizing in its inclusive nature a political rather than ethnic ethos, and reflected in the $19^{\text {th }}$ century slogan "For our liberty and yours", which is supposedly a genuinely Polish and, at the same time, internationalist motto) by no means undermines nationalism.

Analyzing the roots of the hidden assumptions of the Polish citizenship model, with the intelligentsia member as its ideal citizen, one can also point to the model's post-colonial and post-imperial aspects. The intelligentsia, as a specific kind of cultural bourgeoisie, has been and remains a product of the Russian and, to a lesser extent, the Austro-Hungarian empires. This strata has been known as a separate social class only in that part of the world. Even if the intelligentsia was able to abolish empires and become the ruling class in some of the states which emerged from their ruins, one can claim that its emergence and ability to establish a new citizenship model defined in opposition to the old imperial dominant classes is a clear legacy of imperial citizenship. As Anne Spry Rush and Reed (2014) have demonstrated, the heritage of imperial citizenship in newly established post-colonial nations is hard to track, "not least because scholars and politicians have concentrated 
on national development without looking squarely at the colonial past." Yet, as they suggest, a "focus on these national societies in the light of at least some of their peoples' past embrace of imperial identities can be fruitful” (Rush \& Reed, 2014: 505). This assertion provides a relevant insight into the Polish context, where the role of the Russian Empire in shaping the national citizenship model seems to be strongly denied, first of all because Russia and Russians have become a key negative point of reference for the Polish national identity, which just in cases analyzed by Rush and Reed made impossible to look at the Russian role in shaping the citizenship in a more neutral light (Zarycki, 2005). Such a critical look through the lens of Russian and Austrian citizenship and cultural policies inspired by the international debate concerning the characteristics of imperial citizenship could undoubtedly enrich our knowledge of the Polish citizenship model, which has been mostly perceived from a narrowly national perspective.

\section{Poland between the classic models of nation-state building}

The Polish model seems to be considerably different from classic Western models of citizenship, in particular, the French one with its central myth of the French Revolution and the ideal citizen understood as bourgeoise. Following Jack Harrington, the Polish model could be seen as an originally subversive (that is anti-imperial in relation to Austria, Prussia and Russia) appropriation of the French revolutionary heritage (Harrington, 2015: 62). However, its historical framework and narrative seem quite specific. If anything, a comparison to the British model, with its figure of a gentleman as an ideal citizen, would be more relevant. The Polish ideal intelligentsia member has some similarity to a gentleman, even if the model Pole seems more distant from the figure of an entrepreneur. The Polish model cannot be easily inscribed into the classic opposition of French citizenship based on the law of the land (jus soli) or German citizenship based on the law of blood (jus sanguinis). Let us recall here how Rogers Brubaker has reconstructed this opposition in his seminal Citizenship and Nationhood in France and Germany (Brubaker, 1992). His work points to an opposition between the state-centered and assimilationist approach to French nationhood inspired by the Enlightenment political vision of the nation, and the Volk-centered and differentialist Romanticism-inspired anti-Enlightenment cultural conception of the nation expressed in the German case. The French model achieved high levels of universalization, largely due to the attractiveness of French culture, although, as Brubaker has noted, French universalism was weakened by the lost 1870 war with Germany. What was, nevertheless, characteristic for 19th century France was its confidence in its 'inclusiveness', based on the global attractiveness of French culture and its "civilization." This facilitated the articulation of rhetoric of inclusion, the importance of being French "in the heart," placed centrally in that model.

What we can now posit is that, during the interwar period, the Polish model of citizenship was torn by similar contradictions stemming from much weaker state capabilities, not only compared to 19th century France, but also to Germany. Andrzej Walicki, for instance, noted that both Polish nationalism and Polish liberalism 
emerged without capitalism and without the nation-state (Walicki, 1982). Therefore, Walicki claims that the opposition between a ,political nation" based on law and an „ethnic/cultural nation” based on language and common culture, first proposed by Friedrich Meinecke (Meinecke, 1919), is a false one in reference to Poland ${ }^{5}$.

This opposition was later criticized by several other scholars, most notably by Rogers Brubaker (Brubaker, 1998) and Krzysztof Jaskułowski (Jaskułowski, 2010). They have pointed to a simplistic and strongly normative distinction between a "good" nationalism, associated with the West, and "bad" nationalism, allegedly typical for the non-Western world. According to Walicki, this opposition has been typically used for deprecating countries of Central and Eastern Europe, although, as he noted, Germany also happens to be its victim at times as it is allegedly not fully compatible with the ideal French model. One can thus talk about the orientalization of most non-Western models of citizenship, in particular, those distinctively different from the French ideal of the nation-state understood as a critical point of reference (Boatcă, 2017). This may be seen as an aspect of what can be called the post- or neo-colonial status of Central and Eastern Europe. The region remains dependent on the Western core, thus CEE is under a particularly critical eye that constantly measures its degree of adaptation of Western models, which also include ideal visions of citizenship (Melegh, 2006).

Following up on the important contribution of Walicki, we should add that, according to him, the Polish civic model was neither ethnic, that is East-European in Meinecke's terms, neither purely political that is "Western". In his view, the Polish Romanticism, which inspired the Polish 19th-century uprisings of 1831 and 1863, produced a supra-ethnic ideological project which should not be identified as based on "ethnic" criteria of Polishness (Walicki, 1989). It was, rather, a reflection of an idea of a political community of free citizens opposed to the image of Russian and other empires presented as oppressive "prisons of the nations." The post-uprising phase of the development of Polish nationalism, or the final three decades of the 19th century, were dominated by ideologies which implied a decoupling of nation and state but were also directed toward the civic identity building process.

The competition between the two models of the Polish nation-state best incarnated by the Dmowski-Piłsudski conflict has also been reflected in constant tensions between the notions of "citizenship" (obywatelstwo) and "nationality" or "ethnicity" (narodowość) in Poland. These tensions are manifest in most Polish modern constitutions, starting with the so-called March Constitution of 1921 and ending with the

\footnotetext{
5 Theoretically, in different times in its history, Poland has exemplified both "political" (1560-1795) and ethnic (cultural) (1795-1918) versions of national identity and national belonging. However, in neither of these periods was there a clear case of the one-dimensional model. The so-called First Republic (Rzeczpospolita), even if formally a political community of nobles equal in rights, saw gradual domination of Roman Catholicism, which was eventually formally declared the state religion in the May 3rd, 1791, Constitution. During the 19th century, although the Polish state did not exist, a political community inherited from the First Republic continued to exist, at least until the January uprising of 1863, in which Belarusian and Lithuanian speaking units and commanders were participating. Only later, in the 19th century, a more cultural definition of Polishness started to prevail, but it was never a clearly defined issue of language or religious criteria.
} 
current constitution adopted in 1997. For the latter, the "Polish nation" is defined as "all citizens" of the republic. At the same time "ethnicity" (narodowość) other than Polish may be declared by Polish citizens in the census. It should be emphasized that most CEE countries have a clear distinction between notions of "citizenship" and "ethnicity/nationality" in which the latter is usually the equivalent of the Western notion of ethnicity ${ }^{6}$. This distinction has been strongly institutionalized in several states, most notably in the Soviet Union, where so-called "internal passports" had the rubric of "nationality" (Brubaker, 1994). Another recent Polish incarnation of that tension is found in the debate over the so-called "card of a Pole" (Karta Polaka), which is a document issued to ethnic Poles who are citizens of the countries of the former Soviet Union (Górny \& Pudzianowska, 2009; Sendhardt, 2017). This paper's scope does not allow for a discussion of all these conflicts and diverse modes of exclusion and inclusion. Our main argument suggests that these tensions, which cannot be discussed in more detail here and which are often strongly politicized, do not challenge what can be seen as the naturalized, implicit core of the Polish citizenship model analyzed in the central part of this paper. As we argue, that strongly naturalized core of the Polish citizenship model is shared by all factions of the Polish political spectrum. Specific uses of that frame, in particular, acts of exclusion justified with it may have a political character, however, the very frame remains largely uncontested. In the perspective of this analysis, a universalized ideal citizen is a cultured intelligentsia member of gentry origin. His/her central symbolic position in Polish cultural and social hierarchies remains, not only unchallenged but almost invisible ${ }^{7}$.

Whatever the political orientation of contemporary Poles, they will unconsciously aspire to meet the civic ideal personified by exemplary intelligentsia members, and at the same time, they will usually justify criticism of their opponents by undermining their credentials as perfect Polish citizens defined through this intelligentsia lens. Thus, as we argue, there exists a processional, agonistic dimension and a basic, standardized code or mental scheme within the Polish concept of belonging. All the political struggles concern particular meanings of that basic classification, while the intelligentsia scheme remains permanent. It is, therefore, a history that has become nature, while our text can be regarded as its historicization and thus denaturalization, an "anamnesis of the hidden constants", as Bourdieu would call it. By the very fact that the intelligentsia model of citizenship has transformed itself into a naturalized,

\footnotetext{
${ }^{6}$ The list of acts of large-scale exclusion and citizenship-related tensions between diverse modes of belonging (ethnic, civic, religious and other), which happened historically in Poland and are still taking place all over Central and Eastern Europe, would be very long. For example, the question of the Roma in Hungary or Slovakia, or other long-term ethnic minorities in countries of the former Yugoslavia are generating considerable tensions at the current time. However, as mentioned above, this paper is focused primarily on naturalized cultural frames of citizenship in Poland, rather than their openly politicized aspects related to, among other things, ethnic dimensions of Polishness

7 Among individuals who can be considered as exemplary intelligentsia members such historical figures could be mentioned as pope John Paul $2^{\text {nd }}$, Jerzy Giedroyć (founder of the "Kultura" monthly), or Polish war heroes Witold Pilecki or Jan Karski. In fact most $20^{\text {th }}$ century "famous" Poles are intelligentsia members, including most of the Noble prize winners (e.g Maria Skłodowska-Curie, Henryk Sienkiewicz, Czesław Miłosz or Olga Tokarczuk). One major exception would be of course Lech Wałęsa.
} 
invisible code, which is the basis of most of the political struggles and subsequent particular classifications, it remains especially effective in organizing a social vision and thus legitimizing the position of the intelligentsia itself as a social group.

\section{Perception of the Polish model of citizenship in Russia and other countries in Central and Eastern Europe}

To gain additional insight into the specifics of the Polish model of citizenship, it is very useful to look at its external perception. The specific nature of the Polish model of citizenship is not well known in Western countries. It is sometimes included in the above-mentioned generalized model of Eastern European citizenship, based on strongly exclusive ethnic and religious categories. Better recognition of the specific Polish civic model, however, persists in the East. In Russia, to this day, the concept of "Lordly Poland" (Pańska Polska or Panskaya Polsha in Russian) retains a certain currency. This notion may be understood as a synonym of the "noble nation" and was created during the Bolshevik Revolution. The concept of "Lordly Poland" is essentially pejorative, however, in the sense that people reaching for it will recognize Poland as an undemocratic and haughty country. At the same time, it is an expression of the perception of a separate model of citizenship, based on noble values. The Poles in Russia, to this day, are often referred to as Polish "pan"(sir), so in a way, they are treated as citizens of a state based on a universal nobility valuedriven ideology (Heller, 1982). A nationalist-minded publicist, Stanislav Kuniayev, published an essay on Polish-Russian relations under the prominent title of "The Nobles (szlachta) and We" (Kunayev, 2002). In Russian literature, there is no shortage of similar elements defining Polishness as a lofty "lordship" (pańskość) standing in opposition to Russian culture, presumably also much more egalitarian, because of the role of the peasant community understood as an important social ideal. The most famous motifs of this type include the image of Poles in Dostoyevsky's prose, but there are also other examples of works in which a negatively defined Pole is offending the Russians by manifesting his variously defined lordliness ${ }^{8}$.

An expression of this nobility can be, for example, embodied by its irritating, pathetic haughtiness, ostentatious and principled "honorability" or the proud politeness of the interlocutors. All these behaviors are perceived as Polish and characteristic of their "noble" exaltation, pride, and arrogance. This perception of Polish society in the West appears very rarely. Poles are rather defined in a classical orientalist scheme as representatives of the peasant-worker class society, which - it is implicitly assumed - should follow the path of imitation of Western countries until a model of civil society based on bourgeoise ideals is achieved.

The identification of the image of the Poles with the nobility may also reflect an echo of communist propaganda, which was particularly intensively used in the first

\footnotetext{
${ }^{8}$ Ewa Thompson (2000) provides several examples of exoticization of the Poles in the $19^{\text {th }}$ century as well as in contemporary Russian literature. Her examples include prose of Dostoyevsky and Solzhenitsyn, and literary scholars such as Victor Shklovsky and Dmitry Likhachev.
} 
period of the existence of the Soviet state. The slogan of "Lordly Poland" as a hostile state, not only to the Soviet Union but also to the Polish peasants who were encouraged to fight with the "landowners", was quite widely propagated in the 1920s and 1930s. Variants of that slogan appeared, for example, on numerous posters on which the Polish nobility was portrayed as the ruthless oppressor of the "working people of cities and villages". This picture, actively disseminated during the Polish-Bolshevik war of 1920, could be interpreted as an advertisement for the Soviet civic community and certainly shaped, to some extent, stereotypical ideas about Poland in Russia and Belarus that persist to this day. This constant tension between Polish and Russian/Soviet perceptions of their respective citizenship models underscores substantial differences between them. In Russia, at least from the Soviet period onwards, the figure of the ideal intelligentsia member is overshadowed by a patriotic and devoted civil servant or soldier.

The reverse and partly constitutive aspect of the Russian or Belarusian image of the Poles as a nation of arrogant "lords" functions in Poland in the form of negative stereotypes of Russians and other nations east of Poland, which are perceived as strongly peasant or post-communist, and overly "boorish." This "boorishness" can also be associated with negative and strongly orientalist images of the Soviet legacy and understood as a barbarian, with the paradigmatic embodiment of Homo Sovieticus understood as one of the incarnations of the mythical "boor." These images fit well into the broader framework of orientalistic visions present in Polish discourses of a differently defined but invariably depreciated "East" (Zarycki, 2014). These discourses, on the other hand, can be linked with the orientalist ideas of Eastern and Southeastern Europe as a kind of backward and exotic periphery of modern Western Europe. In these visions, as it was pointed out, among others, by Merje Kuus (2007: 27), a strong motif of the peasant character of imaginary Eastern Europe is recurring, which is also invariably juxtaposed with cyclical eruptions of unbridled nationalism.

Since the noble elites of the lands belonging to contemporary Belarus, Lithuania, and Ukraine had gradually become Polonized over the 16th and 17th centuries, the new states in question could not easily reach for a common historical heritage of the Polish-Lithuanian Commonwealth. As a result, when national intelligentsias of these countries in the 19th century shaped their contemporary forms of citizenship, they usually avoided symbolism similar to the Polish universalization of nobility as a civic tradition. Their modern national culture, although built to a large extent by the intelligentsia, appealed to peasant tradition and culture rather than to a noble tradition and culture. A special exception is the use of the Cossack tradition in Ukraine, which can be considered a transitory tradition between the noble and peasant type. This is because Cossacks considered themselves to be "free men" (unlike peasants) and aspired to membership in the nobility of the Polish-Lithuanian Commonwealth. While some of their members were ennobled, as a group, they were generally denied noble status by the Polish and Lithuanian elite. This is often linked to the Cossack uprisings in the 17th century, which have been sometimes seen as a starting point for the emergence of a modern Ukrainian identity. The use of this tradition, which is neither a peasant nor purely noble one, makes the Ukrainian case a hybrid between Polish and other East European models. Another factor that brings 
the Ukrainian and Polish citizenship models closer is their strong historical proximity. Although the modern Ukrainian nationalism arose similarly to the Lithuanian one (to a great extent in opposition to Polishness) this dependence caused the Polish structural formula to strongly influence the Ukrainian and, to a lesser extent, other nationalisms, which were created or redefined in the late 19th century in Eastern Europe. According to Yaroslav Hrytsak, the Ukrainian national movement proved to be the most intense and effective in these areas, where the Polish movement was also strong (Hrycak, 2009). This relationship could partly result from the Austrian imperial authorities' policy of supporting the Ukrainian national movement as a counterbalance to Polish influences. It was, however, the Polish intellectuals, not Austrian officials or other actors, who influenced the imagination and political programs of the intelligentsia that formed competitive national models by, first of all, providing them with basic symbolic categories. Hrytsak even concluded that "Polish nationalism played in the history of Eastern Europe more or less the same role as French nationalism in Western Europe. It brought other nations with Polishness, giving them ready-made ideological and political formulas. It is no coincidence that both the Ukrainian and Israeli ${ }^{9}$ national anthems begin with similar verses: "Ukraine has not yet died / Our hope is not yet dead", which is nothing more than a Polish remake "Poland Is Not Yet Lost" (Hrycak, 2009: 248). The same author also indicates that the achievement in Galicia by the Polish model of the aforementioned, partially universal, status, was also possible because it had previously clearly won the competition with the Austrian model. However, as pointed out by Anna Sosnowska (Sosnowska 2008), in the Eastern European countries neighboring Poland there is no a clear post-noble opposition "lord-boor." Perhaps they have a more egalitarian civic culture than Poland or, more precisely, one closer to the classical Western model, where stratified (post-feudal) hierarchy is supplanted by class (economic) hierarchy. However, one could note that the relative proximity of the Ukrainian citizenship model to the Polish model may be seen as one of the dimensions of the Ukrainian-Russian conflict. Alternatively, it acts as a symbolic division between the two polities that has gained particular relevance to the radicalization of the RussianUkrainian conflict. One aspect of this difference is that the Ukrainian language, just like Polish, has adopted the convention of addressing fellow citizens as "sir" (pan), while its Russian equivalents (e.g., gospodin or barin) have been successfully driven out of use.

\footnotetext{
9 This view seems only to be a hypothesis of Hrytsak, but lyrics of the Israeli anthem known as Hatikvah or "the Hope" are indeed adapted from a poem by Naftali Herz Imber, a Jewish poet from Złoczów (today Zolochiv, Ukraine), located in what was then the Austrian province of Galicja, while the melody derives from "La Mantovana", a 16th-century Italian song, composed by Giuseppe Cenci (Giuseppino del Biado) ca. 1600 (Weiss, 2010).
} 


\section{Conclusions}

Our basic argument on the empirical level of this paper is that there exists a singular and definable modern "Polish concept of belonging," one which can be considered hegemonic. Its core is founded on the primarily naturalized figure of an ideal intelligentsia member. Of course, our account can be criticized as partly intelligentsia-centered, but this seems somewhat inevitable given the current hegemonic status of the intelligentsia in Poland, which does not allow for assuming a completely intelligentsia-distanced point of view. In any case, we do insist that there is a singular, relatively consistent, and hegemonic form of Polish cultural citizenship. This does not mean that there are no variants of that model or that it does not involve any contested aspects. However, our contention is that its essential core has remained largely unchanged since the formation of the Second Polish Republic in 1918. We emphasized, in particular, the distinction between the two dimensions of the Polish citizenship model that we have singled out: the first in which common questions of ethnic, religious, or previous citizenship status are central and often politically debated. The other is at the core of our analysis based on deeply naturalized cultural patterns built around the figure of the ideal intelligentsia member. As we argue, this model has never been effectively challenged since 1918. We view most of the 19th century as a period of tension between different citizenship models. Communists in the Stalinist period made some attempts at remaking the intelligentsia hegemony, but ultimately they have failed. Most importantly, all the contemporary Polish political parties share the critical assumptions of the model and try to present their leaders as ideal Polish intelligentsia members. Therefore, we argue that late Polish communists, the socalled-post communists, liberals, and well as leaders of the Law and Justice party and most others Polish politicians all speak the same political language of Polish identity, one in which ideals of the intelligentsia appear as an uncontested point of reference. What is at stake in each of the political conflicts is the question of which of the political leaders will be considered a better incarnation of the ideal intelligentsia member by the wider public, in which political commentators and public intellectuals play particularly crucial role.

At a more theoretical level our paper offered an application of notions of the model citizen, culturalization of citizenship and that of the civil sphere to the study of the historical development of contemporary citizenship in a Central European nation, one which emerged from the fall of the European empires in 1918 but whose roots predate the establishment (or re-establishment as some would prefer) of the given modern nation-state, in our case Poland. Our study has shown how such a historical analysis can be informed by critical sociological approaches to modern Western citizenship, such as those of Jeffery Alexander and T. H. Marshall. Specifically, we argued that definitions and representations of the ideal citizen are important means of political contestation both within polities and between them, often drawing on notions of cultural superiority and inferiority. In this way we have proposed a new insight into the national polities emerging within the European empires at the turn of the $20^{\text {th }}$ century. Moreover, the Polish 
case suggests that culturalization of citizenship is hardly a new phenomenon. It can be seen as a primary mechanism in the formation of civic polities within an imperial context which only later get institutionalized and became legitimized by nation states. Thus, what the Polish case also illustrates is that culturalization reveals itself as an important aspect of the citizenship formation processes within the imperial and colonial context. Moreover, it shows that such processes can have many ambiguous aspects as far as their Orientalizing forces of exclusion are concerned. Thus, the emerging Polish intelligentsia-centered citizenship model has been used as an Orientalizing machinery towards peasants who lack sufficient levels of cultural capital. That was the case for Polish peasants and for those of Belarussian, Lithuanian and, in particular, Ukrainian ethnicity. This orientalization was, and still sometimes can be noted as present, also in the more inclusive versions of the Polish citizenship model (such as the political, federalist nation concept, which was related to Józef Piłsudski’s visions.). Finally, the Polish citizenship model can be and sometimes is Orientalized by Russians, as well by Westerners, in particular by mainstream Anglo-American-centered scholarship of citizenship.

Our project can thus be viewed as an attempt to inscribe classic analyses of the historical genesis of the citizenship model into a transnational history of the transformation of European empires to Central and Eastern European nation-states. It may be also related to the study of subaltern citizenship projects in other parts of the world marked by complex relations between imperial and fragmented national groups. Above all, it points to the importance of the historical roots of largely naturalized normative citizenship models, especially those which produce less salient yet important dimensions of domination, besides the widely discussed issues of ethnic, religious or linguistic identities. And these dimensions of domination persist, as we have shown how a symbolic hierarchy produced by a historical confrontation of elite factions in the late $19^{\text {th }}$ century has continued to sustain modern social hierarchies in a nation-state.

Funding This study was funded by the National Science Centre of Poland (NCN), grant no. 2015/17/B/ HS6/04161 granted to Tomasz Zarycki and grant no. grant no. 2011/03/B/ HS6/03971 granted to Rafał Smoczyński.

\section{Declarations}

Conflict of Interest The authors declare that they have no conflict of interest.

Open Access This article is licensed under a Creative Commons Attribution 4.0 International License, which permits use, sharing, adaptation, distribution and reproduction in any medium or format, as long as you give appropriate credit to the original author(s) and the source, provide a link to the Creative Commons licence, and indicate if changes were made. The images or other third party material in this article are included in the article's Creative Commons licence, unless indicated otherwise in a credit line to the material. If material is not included in the article's Creative Commons licence and your intended use is not permitted by statutory regulation or exceeds the permitted use, you will need to obtain permission directly from the copyright holder. To view a copy of this licence, visit http://creativecommons.org/licen ses/by/4.0/. 


\section{References}

Alexander, J. C. (2006). The Civil Sphere. Oxford University Press.

Alexander, J. C. (2012). Trauma: A Social Theory. Polity.

Bajer, M. (2013). Rody uczone. Kreski do szkicu. Wydawnictwa UMK.

Bajer, M. (2019). Rody uczone: Kreski do szkicu 2. Wydawnictwo UMK.

Bakić-Hayden, M. (1995). Nesting Orientalisms: The Case of Former Yugoslavia. Slavic Review, 54(4), 917-931.

Beatty, A. (2016). An Irish Revolution without a Revolution. Journal of World-Systems Research, 22(1), 23.

Bilewicz, A. (2015). Odnowa etosu społecznikowskiego? O inteligenckim charakterze niezinstytucjonalizowanych inicjatyw społecznych. In G. Chimiak, \& K. Iwińska (Eds.), Krajobraz społecznościowy - Polska 2014 (pp.7-75). Collegium Civitas-CAL.

Boatcă, M. (2017). Modernity, Citizenship and Occidentalist Epistemology in Max Weber and Beyond. TRAFO - Blog for Transregional Research, 22(06), 2017 (https://trafo.hypotheses.org/7005)

Bourdieu, P. (1984). Distinction. A Social Critique of the Judgement of Taste. Harvard University Press.

Boll, C., Rossen, A., \& Wolf, A. (2017). The EU Gender Earnings Gap: Job Segregation and Working Time as Driving Factors. Jahrbücher für Nationalökonomie und Statistik, 237, 407-452.

Böhler, J. (2018). Civil War in Central Europe, 1918-1921: The Reconstruction of Poland. Oxford University Press.

Brubaker, R. (1992). Citizenship and Nationhood in France and Germany. Harvard University Press.

Brubaker, R. (1994). Nationhood and the National Question in the Soviet Union and Post-Soviet Eurasia: An Institutionalist Account. Theory and Society, 23(1), 47-78.

Brubaker, R. (1996). Nationalism Reframed. Nationhood and the National Question in the New Europe. Cambridge University Press.

Brubaker, R. (1998). Myths and Misconceptions in the Study of Nationalism. In J. Hall (Ed.), The State of the Nation: Ernest Gellner and the Theory of Nationalism (pp. 272-306). Cambridge University Press.

Buchowski, M. (2006). The Specter of Orientalism in Europe: From Exotic Other to Stigmatized Brother. Anthropological Quarterly, 79(3), 463-482.

Carens, J. H. (1987). Aliens and Citizens: The Case for Open Borders. The Review of Politics, 49(2), 251-273.

Cobel-Tokarska, M. (2020). Problems and contradictions in Polish postcolonial thought in relation to Central and Eastern Europe. Postcolonial Studies, 1-20.

Dawson, P. (1993). Introduction. In R. Waldinger, P. Dawson, \& I. Woloch (Eds.), The French Revolution and the Meaning of Citizenship. Greenwood Press.

Domański, H., Słomczyński, K. M., \& Sawiński, Z. (2018). Changes in Occupational Prestige, 19582008. In I. Tomescu-Dubrow, K. M. Słomczyński, H. Domański, J. K. Dubrow, Z. Sawiński, \& I. D. Przybysz (Eds.), Dynamics of Class and Stratification in Poland (pp. 173-200). Central European University Press.

Dunin-Kozicka, M. (1925). Burza Od Wschodu: Wspomnienia Z Kijowszczyzny (1918-1920). Krakowska Spółka Wydawnicza.

Eyal, G., \& Townsley, E. (1995). The social composition of the Communist nomenklatura: A comparison of Russia, Poland, and Hungary. Theory and Society, 24(5), 723-750.

Eyal, G., Szelényi, I., \& Townsley, E. R. (1998). Making Capitalism without Capitalists. In Class Formation and Elite Struggles in Post-Communist Central Europe. Verso.

Fink, C. (2006). Defending the Rights of Others: The Great Powers, the Jews, and International Minority Protection, 1878-1938. Cambridge University Press.

Foucault, M. (1980). Power/Knowledge. Selected Interviews and Other Writings, 1972-1977. Pantheon Books.

Gawin, M. (2015). Spór o równouprawnienie kobiet (1864-1919). Instytut Historii PAN, Polskie Towarzystwo Historyczne, Wydawnictwo Neriton.

Gella, A. (1976). An Introduction to the Sociology of the Intelligentsia. In A. Gella (Ed.), The Intelligentsia and the Intellectuals. Theory, Method, and Case Study. (pp. 9-34). Sage.

Grabski, W. (2016). Idea Polski: Wybór Pism. Ośrodek Myśli Politycznej, Narodowe Centrum Kultury.

Grocholski, Z. (1929). Kresowe Ziemie Ruskie Najjaśniejszej Rzeczypospolitej. Nakładem Koła Polaków Ziem Ruskich. 
Go, J. (2009). The 'New' Sociology of Empire and Colonialism. Sociology Compass, 3, 775-788.

Górny, A., \& Pudzianowska, D. (2009). Same Letter, New Spirit: Nationality Regulations and Their Implementation in Poland. In R. Bauböck, B. Perchinig, \& W. Sievers (Eds.), Citizenship Policies in the New Europe (pp. 123-149). Amsterdam University Press.

Górny, A., Grzymała-Kazlowska, A., Koryś, P., \& Weinar, A. (2005). Selective Tolerance? Regulations, Practice and Discussions Regarding Dual Nationality in Poland. In T. Faist Dual (Ed.), Citizenship in Europe: From Nationhood to Societal Integration (pp. 147-169). Ashgate.

Harrington, J. (2015). The Imperial Citizen: British India and French Algeria. In E. F. Isin (Ed.), Citizenship after Orientalism: Transforming Political Theory (pp. 53-69). Palgrave Macmillan.

Heater, D. B. (2004). A brief history of citizenship. New York University Press.

Heller, M. (1982). Polskie pany. Kultura 421 (October 1982)

Horolets, A., \& Bielecka-Prus, J. (2016). Szlachecko-inteligencki punkt widzenia na polską emigrację. Przypadek "Kultury" paryskiej. Przeglad Polonijny, 4, 97-122.

Horolets, A., and J.Bielecka-Prus. (2017). Strategia wykluczania w reprezentacajch polskiej emigracji na łamach paryskiej "Kultury" (1947-2000). In: M. Czyżewski, A. Horolets, K. Podemski, i D. Rancew-Sikora (ed.) Polskie sprawy 1945-2015. (pp. 21-61) : Wydawnictwo Akademickie Sedno.

Hrycak, J. (2009). Nowa Ukraina. Nowe Interpretacje. Kolegium Europy Wschodniej im. Jana Nowaka-Jeziorańskiego.

Isin, E. F. (2015). Transforming Political Theory. In E. F. Isin (Ed.), Citizenship after Orientalism: Transforming Political Theory (pp. 1-13). Palgrave Macmillan.

Jakubowska, L. (2012). Patrons of History: Nobility, Capital and Political Transitions in Poland. Ashgate.

Jaskułowski, K. (2010). Western (Civic) Versus Eastern (Ethnic) Nationalism. The Origins and Critique of the Dichotomy. Polish Sociological Review, 3(171), 289-303.

Jaszczuk, A. (1999). Liberalna Atlantyda: Główne nurty liberalizmu polskiego 1870-1939 r. Warszawa: KB.

Jedlicki, J. (1999). A Suburb of Europe. Nineteenth-Century Polish Approaches to Western Civilization. Central European University Press.

Kauffman, J. (2015). Elusive Alliance: The German Occupation of Poland in World War I. Harvard University Press.

Kehr, E. (1965). Der Primat der Innenpolitik. Gesammelte Aufsätze zur preussisch-deutschen Sozialgeschichte im 19. und 20. Jahrhundert. de Gruyter.

Kennedy, M. D. (1992). The intelligentsia in the constitution of civil societies and post- $\backslash$ communist regimes in. Hungary and Poland Theory and Society, 21(1), 29-76.

Kešić, J., \& Duyvendak, J. W. (2016). Anti-Nationalist Nationalism: The Paradox of Dutch National Identity. Nations and Nationalism, 22(3), 581-597.

Kossak, Z. (1923). Pożoga: Wspomnienia Z Wołynia, 1917-1919. Nakładem Krakowskiej Spółki Wydawniczej.

Kulas, P. (2017). Inteligenckość zaprzeczona. Etos i tożsamość młodych inteligenckich elit. Wydawnictwo Naukowe Scholar.

Kunayev, S. (2002). Shliakhta i My. Nash Sovremennik, 5, 82-135.

Kuus, M. (2007). Geopolitics Reframed: Security and Identity in Europe's Eastern Enlargement. Palgrave Macmillan.

Liebich, A. (2009). Introduction: Altneuländer or the Vicissitudes of Citizenship in the New EU States. In R. Bauböck, B. Perchinig, \& W. Sievers (Eds.), Citizenship Policies in the New Europe. (pp. 21-44). Amsterdam University Press.

Łysko, M. (2015). Udział kobiet w życiu publicznym II Rzeczypospolitej Polskiej. Miscellanea Historico-Iuridica XIV, 1, 381-400.

Marshall, T. H. (1964). Class, Citizenship, and Social Development; Essays. Doubleday.

Maj, E. (2017). „Ziemianka” - organ prasowy Zjednoczonego Koła Ziemianek 1908-1919. In: M. Dajnowicz i A. Miodowski (ed.) Polityka i politycy w prasie XX i XXI wieku. Prasa organizacji politycznych. (pp. 15-29) Białystok: Wydawnictwo HUMANICA Instytut Studiów Kobiecych

Marzec, W. (2020). Rising Subjects: The 1905 Revolution and the Origins of Modern Polish Politics. University of Pittsburgh Press.

Meinecke, F. (1919). Weltbürgertum und Nationalstaat:Studien Zur Genesis Des Deutschen Nationalstaates. R. Oldenbourg.

Melegh, A. (2006). On the East-West Slope: Globalization, Narration, Racism and Discourses on Central and Eastern Europe. CEU Press. 
Mich, W. (2000). Ideologia Polskiego Ziemiaństwa 1918-1939. Wydawnictwo UMSC.

Morson, G. S. (1993). What Is the intelligentsia? Once More, an Old Russian Question. Academic Questions, 6(3), 20-38.

Nałęcz, D. (1994). Sen o władzy: Inteligencja wobec niepodległości. Państwowy Instytut Wydawniczy.

Ní Mhurchú, A. (2014). Citizenship Beyond State Sovereignty. In Engin F. Isin and Peter Nyers. Routledge Handbook of Global Citizenship Studies. (pp. 119-127). Routledge.

Ossowska, M. (1986). Bourgeois Morality. Routledge \& Kegan Paul.

Pakulski, J. (1997). Cultural citizenship. Citizenship Studies, 1(1), 73-86.

Pokoj, J. (2014). Regulacja prawna obywatelstwa polskiego w pierwszych latach II RR (1918-1926). Internetowy Przeglad Prawniczy TBSP UJ, 2014(14), 23-40.

Popiński, K. (2018). System szkolnictwa wyższego w II Rzeczypospolitej i jego wpływ na funkcjonowanie uczelni polskich po 1945 roku. Społeczeństwo i ekonomia, 1, 25-53.

Popiński, K. (2019). Feminization of Higher Education in Poland in 1918-2018. Studia historiae oeconomicae, 37, 116-146.

Porter, B. (2011). Faith and fatherland: Catholicism, modernity, and Poland. Oxford University Press.

Radiukiewicz, A. (2021). Obrońcy demokracji: Tożsamość ruchu społecznego i jej źródta. NOMOS, ISP PAN.

Ringer, F. (2004). Admissions. In W. Rüegg (Ed.), A History of the University in Europe: Volume 3, Universities in the Nineteenth and Early Twentieth Centuries (1800-1945), (pp. 233-268). Cambridge University Press.

Rush, A., \& Reed, C. V. (2014). Imperial Citizenship in a British World. In E. F. Isin \& P. Nyers (Eds.), Routledge Handbook of Global Citizenship Studies. (pp. 498-507). Routledge.

Sdvižkov, D. A. (2006). Das Zeitalter der Intelligenz: zur vergleichenden Geschichte der Gebildeten in Europa bis zum Ersten Weltkrieg. Vandenhoeck \& Ruprecht.

Sharp, A. (1991). The Versailles Settlement: Peacemaking in Paris, 1919. Macmillan.

Sendhardt, B. (2017). Theorizing the Karta Polaka. The Journal of Power Institutions in Post-Soviet Societies, 18

Smoczynski, R., Fitzgerald, I., \& Zarycki, T. (2017). The intelligentsia informed habitus in social distance strategies of Polish migrants in the UK. Ethnic and Racial Studies, 40, 951-968.

Smoczyński, R., \& Zarycki, T. (2021). The Extended Family: Descendants of Nobility in Post-communist Poland. Communist and Post-Communist Studies, 54(4), 157-175.

Steinmetz, G. (2014). The Sociology of Empires, Colonialism, and Postcolonialism. Annual Review of Sociology, 40, 77-103.

Tazbir, J. (2013). Kultura szlachecka w Polsce. Rozkwit-upadek-relikty. Wydawnictwo Nauka i Innowacje.

Thompson, E. (2000). Imperial knowledge. Russian literature and colonialism. Greenwood Press.

Tchouikina, S. (2006). Le «Grand Compromis» et la mémoire familiale: Les ex-nobles Russes a l'époque Stalinienne. Revue d'études comparatives Est-Ouest, 37(3), 165-197.

Tonkens, E., \& Duyvendak, J. W. (2016). Introduction: The Culturalization of Citizenship. In J. W. Duyvendak, P. Geschiere, \& E. Tonkens (Eds.), The Culturalization of Citizenship: Belonging and Polarization in a Globalizing World (pp. 1-20). Palgrave Macmillian.

Turner, B. S. (1997). Citizenship studies: A general theory. Citizenship Studies, 1(1), 5-18.

Vermeersch, P. (2009). Poland: Minority Policies in a Homogenized State. In B. Rechel (Ed.), Minority Rights in Central and Eastern Europe. (pp. 166-179). Routledge.

Walicki, A. (1982). Philosophy and Romantic Nationalism. The Case of Poland. Clarendon Press, Oxford.

Walicki, A. (1989). The Enlightenment and the Birth of Modern Nationhood: Polish Political Thought from Noble Republicanism to Tadeusz Kosciuszko. University of Notre Dame Press.

Walicki, A. (2005). Polish conception of the intelligentsia and its calling. In F. Bjorling \& A. PereswetoffMorath (Eds.), Words, deeds and values. The intelligentsias in Russia and Poland during the nineteenth and twentieth centuries. (pp. 1-22) Lund: Department of East and Central European Studies. Lund University.

Wallerstein, I. M. (1974-1989). The Modern World System (Vol. 3 vols). Academic Press.

Weber, M. (1968). Economy and society: an outline of interpretive sociology. Bedminster Press.

Wegner, K. L. (2014). Can There Be a Global Historiography of Citizenship? In E. F. Isin \& P. Nyers (Eds.), Routledge Handbook of Global Citizenship Studies (pp. 139-149). Routledge.

Weiss, J. (2010). The Lemberg Mosaic. Alderbrook Press.

Weredyńska-Szpakowska, M. (2016). Podstawy Prawne Nabycia Obywatelstwa Polskiego Po 1918 Roku - Ziemie Byłego Zaboru Austriackiego. Studia z Dziejów Pańswa i Prawa Polskiego / Studies in History of Polish State and Law XIX:221-44 
Zarycki, T. (2004). Uses of Russia: The Role of Russia in the Modern Polish National Identity. East European Politics and Societies, 18, 595-627.

Zarycki, T. (2014). Ideologies of Eastness in Central and Eastern Europe. Routledge.

Zarycki, T. (2015). Class Analysis in Conditions of a Dual-Stratification Order. East European Politics \& Societies, 29(3), 711-718.

Zysiak, A. (2016). Punkty za pochodzenie: Powojenna modernizacja i uniwersytet w robotniczym mieście. NOMOS.

Publisher's note Springer Nature remains neutral with regard to jurisdictional claims in published maps and institutional affiliations. 